\title{
Molecular identification and population genetic study of Elaeidobius kamerunicus Faust. (Coleoptera: Curculionidae) from Indonesia, Malaysia and Cameroon based on mitochondrial gene
}

\author{
VAN BASTEN TAMBUNAN ${ }^{1,3}$, ARDHA APRIYANTO ${ }^{2,3}$, WALTER AJAMBANG ${ }^{4, \boldsymbol{v}}$, \\ CULBERTSON ENOW ETTA ${ }^{5, v \vee}$, BANDUNG SAHARI $^{3}$, DAMAYANTI BUCHORI $^{6}$, PURNAMA HIDAYAT $^{6, v v v}$ \\ ${ }^{1}$ Program of Entomology, Graduate School, Institut Pertanian Bogor. Jl. Lingkar Akademik, Kampus Dramaga, Bogor 16680, West Java, Indonesia \\ ${ }^{2}$ Biopolymer Analytics, Institute of Biochemistry and Biology, University of Potsdam. Karl-Liebknecht-Str., 14476 Potsdam-Golm, Germany. \\ ${ }^{3}$ PT. Astra Agro Lestari Tbk. Pulogadung Industrial Area, Jakarta Timur 13920, Jakarta, Indonesia \\ ${ }^{4}$ Oil Palm Research Program, Institut of Agricultural Research for Development Douala. B. P. 2123, Messa-Yaounde, Cameroon. \\ Tel.: +237-22-223362, Fax.: +237-22-225924, `email: ajambang@gmail.com \\ ${ }^{5}$ Research Department, Lobe Oil Palm Estate. Pamol Plantations Plc. P.M.B. 03, Ekondo Titi Ndian Division, South West Region, Cameroon \\ Tel.: +237-677-111247. •vemail: culbetta@yahoo.com \\ ${ }^{6}$ Department of Crop Protection, Faculty of Agriculture, Institut Pertanian Bogor. Jl. Lingkar Akademik, Kampus Dramaga, Bogor 16680, West Java, \\ Indonesia. Tel. +62-251-8629354, Fax.: +62-251-8629352, ^^vemail: phidayat@apps.ipb.ac.id
}

Manuscript received: 27 December 2019. Revision accepted: 24 June 2020

\begin{abstract}
Tambunan VB, Apriyanto A, Ajambang W, Etta CE, Sahari B, Buchori D, Hidayat P. 2020. Molecular identification and population genetic study of Elaeidobius kamerunicus Faust. (Coleoptera: Curculionidae) from Indonesia, Malaysia and Cameroon based on mitochondrial gene. Biodiversitas 21: 3263-3270. Oil palm pollinating weevil Elaeidobius kamerunicus is a very important insect pollinator in oil palm plantation. However, there is still lack of information about molecular identification and population genetic study in this species. The purpose of this study was to explore the effectiveness of oil palm pollinating weevil identification using mitochondrial DNA of COI gene and to assess its genetic variation between different locations and countries. We sequenced the DNA barcode of 36 individuals of this species using the mtDNA Cytochrome Oxidase I (COI) gene to explore their genetic variation, identity and phylogenetic relationship. The COI gene sequences generated from this study were successful in identifying E. kamerunicus. Phylogenetic analysis also revealed 3 well-supported monophyletic haplogroups of E. kamerunicus population. In addition, genetic differentiation analysis revealed that most populations from Indonesia were different from Malaysian and Cameroonian populations indicating that there was a genetic variation between the population samples from these countries. The overall E. kamerunicus used in this study were geographically structured in two regions; outside Indonesia region (Cameroon and Malaysia) and Indonesia region. These results demonstrate the feasibility of using COI gene sequence for molecular identification and population genetic study of $E$. kamerunicus species.
\end{abstract}

Keywords: COI gene, Elaeidobius kamerunicus, mtDNA, oil palm, weevil

\section{INTRODUCTION}

The oil palm weevil pollinator E. kamerunicus in Indonesia was originated from Cameroon (Africa). Based on the history of its introduction, E. kamerunicus in Indonesia was introduced from Malaysia on July 16, 1982, in collaboration with the Marihat Research Center and PT. London Sumatra, led by an entomologist R. A. Syed. Furthermore, with the permission of the Indonesian Minister of Agriculture, as many as 4623 pupae that later developed into 508 adults of E. kamerunicus were officially released in March 1983 (Lubis 1992). Currently, the population of E. kamerunicus has spread in oil palm plantations in various islands in Indonesia (Bakara 2019). This population is thought to originate from the initial population that was first released in 1983 in Siantar (North Sumatra, Indonesia).

The existence of geographical isolations in a species' population can cause intraspecific genetic diversity of this species (Schmitt and Haubrich 2008; Cox et al. 2016). This had also been demonstrated by research in genetic diversity study of E. kamerunicus in Indonesia using simple sequence repeat (SSR) marker (Bakara 2019).

Cytochrome $\mathrm{c}$ oxidase I (COI) gene markers are common to genetic diversity and phylogenetic studies in animals (Ursing and Arnason 1998). The importance in using COI in animal studies is based on several premises (i) Mitochondrial DNA is abundant in the cell, so it is easy to get the genes in the mitochondria (Crozier and Crozier 1993); (ii) Mitochondrial DNA has a high mutation rate and is inherited maternally; (iii) Mitochondrial DNA does not undergo recombination, so genetic diversification occurs only through mutation (Smith 1991; Hoy 2003); (iv) The differences among nucleotide bases using mitochondrial DNA markers are few so they are expected to be able to identify species accurately (Zein and Prawiradilaga 2013); (v) Recently, COI gene markers were used as a standard for animal species identification through DNA barcoding especially insects (Hebert et al. 2003; Hebert et al. 2016).

In this study, the origin and genetic differentiation of $E$. kamerunicus will be assessed, 30 years after its 
introduction to Malaysia and Indonesia. Genetic information about E. kamerunicus population in Indonesia, Malaysia and Cameroon have never been reported. The purpose of this study was to examine the effectiveness of using mitochondrial DNA barcoding technology in the identification of genetic diversity and population origin in the oil palm pollinating weevil E. kamerunicus.

\section{MATERIALS AND METHODS}

\section{Specimen collection and morphological identification}

This research was carried out from December 2018 to July 2019. The insect samples were taken from oil palm plantations at 6 different locations (Table 1). Three male and female samples for each location were observed, in this study. All individuals were identified to a species level based on morphological characteristics and taxonomic keys under a light microscope. Molecular characterization was carried out at the Biotechnology Laboratory, Astra Agro Lestari, Pangkalan Lada, Central Kalimantan, Indonesia.

\section{DNA extraction, PCR amplification and sequencing}

DNA was isolated from each individual of the weevil imago (Table 1). The DNA isolation process was begun by crushing the weevil's body with a micro-pestle. DNA was isolated using the GS 100-Genaid gSYNCTM DNA Extraction Kit and the process was carried out in accordance with the manufacturer's instructions. The quality and quantity of the isolated DNA were measured using NanoDrop 2000-Thermo Scientific Spectrophotometer. A target 700-bp fragment of COI was amplified by polymerase chain reaction (PCR) using a Veriti Thermal Cycler (Applied Biosystem, USA) with the following primers: E.kam $F$ primer forward (5 'TTGGAGGATTTGGGAATTGACT-3') and E.kam R primer reverse (5 '-TTGCTGAAGTAAAATATGCCCGT$\left.3^{\prime}\right)$. This primer is specifically designed for E. kamerunicus DNA based on laboratory optimization. PCR was performed in $50 \mu \mathrm{l}$ reaction volume containing $5 \mu \mathrm{l}$ genomic DNA, $1 \mu \mathrm{l}$ each forward and reverse primer (20 $\mathrm{mM}$ ), $25 \mu \mathrm{l}$ of MyTaqTM HS Red Mix 2X (Bioline, UK), and $18 \mu \mathrm{l}$ nuclease-free water. The PCR thermal profile was as follows: initial denaturation at $95^{\circ} \mathrm{C}$ for $3 \mathrm{~min} ; 35$ cycles of $95^{\circ} \mathrm{C}$ for $15 \mathrm{~s}, 55^{\circ} \mathrm{C}$ for $15 \mathrm{~s}$, and $72^{\circ} \mathrm{C}$ for $15 \mathrm{~s}$, a final extension at $72{ }^{\circ} \mathrm{C}$ for $5 \mathrm{~min}$ and storage at $4{ }^{\circ} \mathrm{C}$. The PCR products were visualized by $1 \%$ agarose gel electrophoresis stained with GelRed (Biotium). Sequencing was done at First Base, Malaysia using automated DNA sequencing with ABI 3730 XL (Applied Biosystems, USA). The sequencing chromatograms data of $\mathrm{ABI}$ file were assembled and trimmed using Geneious software. Sequences obtained in this study were finally deposited in GenBank with the accession numbers (MN548049MN548084) and shown in Table 2.

\section{Molecular identification and phylogenetic analysis}

The sequences were imported into the Barcode of Life Database (BoLD) System (www.barcodinglife.org) website (Ratnasingham and Hebert 2007) and GenBank database (www.ncbi.nlm.nih) website (Benson et al. 2012) to determine the similarity of the samples with current databases. The sequences of the closest relatives to E. kamerunicus from those databases were used as comparisons (Table 3). All of the sequences were aligned using Clustal W (Larkin et al. 2007) with default parameters. A distance-based and a phylogenetic tree-based approach of species discrimination were used for molecular identification or barcoding analysis. For the distance-based method, the genetic pairwise divergences based on the broadly used Kimura-2parameter model (K2P) were used as implemented in MEGA X (Kumar et al. 2018). For the tree-based approach, a simplified neighbor-joining (NJ) tree was constructed using MEGA X based on Kimura 2-parameter (K2P) distances of COI, with 1000 bootstrap replicates (Kumar et al. 2018). Species delimitation plugin (Rosenberg, 2007; Masters et al. 2011) inside Geneious software was used to determine monophyletic species from the tree.

\section{Population genetic analysis}

DnaSP 6 (Rozas et al. 2017) was performed to calculate number of polymorphic sites (S), number of haplotypes $(\mathrm{H})$, haplotype diversity ( $\mathrm{Hd})$, nucleotide diversity $(\mathrm{Pi})$. Neutrality tests (Tajima's D and Fu's Fs) were performed in Arlequin version 3.51 (Tajima 1989; Fu 1997; Excoffier and Lischer 2010). In addition, haplotype network analysis was performed using the Minimum Spanning Network (MSN) (Bandelt et al. 1999). Clustal W aligned sequences from MEGA $X$ in the previous section were used to create haplotype network. MSN reconstruction was carried out using POPART software (Leigh and Bryant 2015). Geographical structuring of mtDNA variation was examined by a hierarchical analysis of molecular variance (AMOVA) and population pairwise FST values between populations were calculated in ARLEQUIN version 3.51 using the method of (Weir and Cockerham 1984). Fixation indices significantly different from zero were identified by comparison with the results of 10,000 data permutations.

Table 1. Sampling location and number of samples used in this study

\begin{tabular}{|c|c|c|c|c|c|c|c|}
\hline \multirow{2}{*}{ Code } & \multirow{2}{*}{ Country } & \multirow{2}{*}{ Province } & \multirow{2}{*}{ City } & \multicolumn{2}{|c|}{ Geographic location } & \multicolumn{2}{|c|}{ Number of samples } \\
\hline & & & & Lattitude & Longitude & Male & Female \\
\hline $\mathrm{CD}$ & Cameroon & Littoral Region & Douala & 4.600548 & 9.077712 & 3 & 3 \\
\hline MD & Malaysia & Selangor & Dengkil & 2.858722 & 101.68311 & 3 & 3 \\
\hline IS & Indonesia & North Sumatra & Siantar & 2.96825 & 99.15359 & 3 & 3 \\
\hline IB & Indonesia & West Java & Bogor & -6.54899 & 114.86301 & 3 & 3 \\
\hline IT & Indonesia & South Kalimantan & Tapin & -2.72279 & 114.86301 & 3 & 3 \\
\hline IM & Indonesia & Central Sulawesi & Morowali & -2.08419 & 121.46031 & 3 & 3 \\
\hline
\end{tabular}


Table 2. COI sequence obtained in this study

\begin{tabular}{|c|c|c|c|c|c|}
\hline Country & Province & City & Sex & Sample name & $\begin{array}{c}\text { GenBank accession } \\
\text { number }\end{array}$ \\
\hline Cameroon & Littoral Region & Douala & Female & Douala Female 1 & MN548084 \\
\hline Cameroon & Littoral Region & Douala & Female & Douala Female 2 & MN548049 \\
\hline Cameroon & Littoral Region & Douala & Female & Douala Female 3 & MN548050 \\
\hline Cameroon & Littoral Region & Douala & Male & Douala Male 1 & MN548051 \\
\hline Cameroon & Littoral Region & Douala & Male & Douala Male 2 & MN548052 \\
\hline Cameroon & Littoral Region & Douala & Male & Douala Male 3 & MN548053 \\
\hline Indonesia & West Java & Bogor & Female & Dramaga Female 1 & MN548054 \\
\hline Indonesia & West Java & Bogor & Female & Dramaga Female 2 & MN548055 \\
\hline Indonesia & West Java & Bogor & Female & Dramaga Female 3 & MN548056 \\
\hline Indonesia & West Java & Bogor & Male & Dramaga Male 1 & MN548057 \\
\hline Indonesia & West Java & Bogor & Male & Dramaga Male 2 & MN548058 \\
\hline Indonesia & West Java & Bogor & Male & Dramaga Male 3 & MN548059 \\
\hline Indonesia & South Kalimantan & Tapin & Female & Tapin Female 1 & MN548060 \\
\hline Indonesia & South Kalimantan & Tapin & Female & Tapin Female 2 & MN548061 \\
\hline Indonesia & South Kalimantan & Tapin & Female & Tapin Female 3 & MN548062 \\
\hline Indonesia & South Kalimantan & Tapin & Male & Tapin Male 1 & MN548063 \\
\hline Indonesia & South Kalimantan & Tapin & Male & Tapin Male 2 & MN548064 \\
\hline Indonesia & South Kalimantan & Tapin & Male & Tapin Male 3 & MN548065 \\
\hline Indonesia & Central Sulawesi & Morowali & Female & Morowali Female 1 & MN548066 \\
\hline Indonesia & Central Sulawesi & Morowali & Female & Morowali Female 2 & MN548067 \\
\hline Indonesia & Central Sulawesi & Morowali & Female & Morowali Female 3 & MN548068 \\
\hline Indonesia & Central Sulawesi & Morowali & Male & Morowali Male 1 & MN548069 \\
\hline Indonesia & Central Sulawesi & Morowali & Male & Morowali Male 2 & MN548070 \\
\hline Indonesia & Central Sulawesi & Morowali & Male & Morowali Male 3 & MN548071 \\
\hline Indonesia & North Sumatra & Siantar & Female & Siantar Female 1 & MN548072 \\
\hline Indonesia & North Sumatra & Siantar & Female & Siantar Female 2 & MN548073 \\
\hline Indonesia & North Sumatra & Siantar & Female & Siantar Female 3 & MN548074 \\
\hline Indonesia & North Sumatra & Siantar & Male & Siantar Male 1 & MN548075 \\
\hline Indonesia & North Sumatra & Siantar & Male & Siantar Male 2 & MN548076 \\
\hline Indonesia & North Sumatra & Siantar & Male & Siantar Male 3 & MN548077 \\
\hline Malaysia & Selangor & Dengkil & Female & Dengkil Female 1 & MN548078 \\
\hline Malaysia & Selangor & Dengkil & Female & Dengkil Female 2 & MN548079 \\
\hline Malaysia & Selangor & Dengkil & Female & Dengkil Female 3 & MN548080 \\
\hline Malaysia & Selangor & Dengkil & Male & Dengkil Male 1 & MN548081 \\
\hline Malaysia & Selangor & Dengkil & Male & Dengkil Male 2 & MN548082 \\
\hline Malaysia & Selangor & Dengkil & Male & Dengkil Male 3 & MN548083 \\
\hline
\end{tabular}

Table 3. Outgroup COI sequence used in this study

\begin{tabular}{|c|c|c|c|}
\hline Sample name & Family & Species & $\begin{array}{c}\text { GenBank accession } \\
\text { number }\end{array}$ \\
\hline Araucarius major (AY040285) & Curculionidae & Araucarius major & AY040285 \\
\hline Abantiadinus nodipennis (KX191194) & Curculionidae & Abantiadinus nodipennis & KX191194 \\
\hline Amorphocerus talpa (EU310754) & Curculionidae & Amorphocerus talpa & EU310754 \\
\hline Sphenophorus sp. (GU176342) & Curculionidae & Sphenophorus sp. & GU176342 \\
\hline Naupactus xanthographus (GU176345) & Curculionidae & Naupactus xanthographus & GU176345 \\
\hline Hylobitelus xiaoi (JX847496) & Curculionidae & Hylobitelus xiaoi & JX847496 \\
\hline Curculionidae sp. (KM244695) & Curculionidae & Curculionidae sp. & KM244695 \\
\hline Eucryptorrhynchus chinensis (KP410324) & Curculionidae & Eucryptorrhynchus chinensis & KP410324 \\
\hline Eucryptorrhynchus brandti (KP455482) & Curculionidae & Eucryptorrhynchus brandti & KP455482 \\
\hline Sphenophorus sp. (NC_018351) & Curculionidae & Sphenophorus sp. & NC_018351 \\
\hline Rhynchophorus ferrugineus (NC_028535) & Curculionidae & Rhynchophorus ferrugineus & NC_028535 \\
\hline Aegorhinus superciliosus (NC_027577) & Curculionidae & Aegorhinus superciliosus & NC_027577 \\
\hline Hylobitelus xiaoi (NC_022680) & Curculionidae & Hylobitelus xiaoi & NC_022680 \\
\hline Naupactus xanthographus (NC_018354) & Curculionidae & Naupactus xanthographus & NC_018354 \\
\hline Apodrosus epipolevatus (HQ891423) & Curculionidae & Apodrosus epipolevatus & HQ891423 \\
\hline Laemophloeus fasciatus (KP134161) & Curculionidae & Laemophloeus fasciatus & KP134161 \\
\hline Exophthalmus pictus (KT350641) & Curculionidae & Exophthalmus pictus & KT350641 \\
\hline Exophthalmus pictus (KT350642) & Curculionidae & Exophthalmus pictus & KT350642 \\
\hline Scepticus tigrinus (LC108870) & Curculionidae & Scepticus tigrinus & LC108870 \\
\hline Scepticus uniformis (LC108925) & Curculionidae & Scepticus uniformis & LC108925 \\
\hline Meotiorhynchus querendus (LC108949) & Curculionidae & Meotiorhynchus querendus & LC108949 \\
\hline
\end{tabular}




\section{RESULTS AND DISCUSSION}

\section{Molecular identification}

In this study, the power of COI sequence as a DNA barcode was tested for identifying the E. kamerunicus species using distance-based and tree-based methods. The species identification using distance-based (pairwise K2P) is considered success when the barcoding gap between intraspecific and interspecific distance-based was detected. In this study, the intraspecific distribution means that the pairwise K2P distance between E. kamerunicus individuals from all locations. Meanwhile, the interspecific distribution showed the pairwise K2P distance between E. kamerunicus individual with the close relatives species or outgroup. The result of intraspecific and interspecific distance based on COI gene can be seen in Figure 1. The frequency distribution between intraspecific and interspecific distances of pairwise K2P can be differentiated in this study. Based on pairwise K2P, it was inferred that there is a clearly big gap between intraspecific and interspecific distance. Thus, the identification of E. kamerunicus has been successfully demonstrated using this approach.

Another approach using tree-based analysis was conducted to differentiate E. kamerunicus from its closely related taxa (Figure 2). Reconstruction of the phylogeny tree of COI markers was carried out by the Neighborjoining method with K2P distance-based method and bootstrap 1.000. The discrimination performance was assessed by evaluating the proportion of the monophyletic clusters for individuals belonging to the same species in the neighbor-joining tree. The results showed that $E$ .kamerunicus samples from all locations were in one big group in the phylogeny tree while outgroups from other nearby genera formed different groups. Based on these results it can be shown that the COI gene can be used to distinguish E. kamerunicus from its closely related taxa (Bakara et al. 2020).

A neighbor-joining tree based on $\mathrm{K} 2 \mathrm{P}$ distances also uncovered that the E.kamerunicus populations formed three haplogroups (Figure 2), and was used to assess the distinctiveness of the haplogroups with the Species Delimitation Plugin in Geneious software. Within each of the three haplogroups, intergroup distances were significantly bigger than intraclade distances (Table 4). Rosenberg's $\mathrm{P}_{\mathrm{AB}}$ 1.50E-07, 1.40E-05, 1.40E-05, for clades 1,2 , and 3 , respectively, strongly supported that the three haplogroups were reciprocal monophyly (Table 4). All three haplogroups are clearly differentiated from the closest taxon Amorphocerus tarpa and Araucarius major (Figure 2).

Table 4. Species delimitation result

\begin{tabular}{lccc}
\hline \multicolumn{1}{c}{ Haplogroup } & Haplogroup I & Haplogroup II & Haplogroup III \\
\hline Closest Haplogroup & II & III & II \\
Intra Dist & 0.002 & 0.001 & 0.001 \\
Inter Dist-Closest & 0.041 & 0.012 & 0.012 \\
Intra/Inter & 0.05 & 0.09 & 0.09 \\
P ID(Strict) & $0.90(0.78,1.0)$ & $0.73(0.56,0.91)$ & $0.96(0.91,1.0)$ \\
P ID(Liberal) & $0.97(0.87,1.0)$ & $0.96(0.81,1.0)$ & $0.99(0.96,1.0)$ \\
Av(MRCA-tips) & 0.0024 & $6.98 \mathrm{E}-04$ & $8.49 \mathrm{E}-04$ \\
P(Randomly Distinct) & 0.05 & 0.05 & 0.05 \\
Rosenberg's P(AB) & $1.50 \mathrm{E}-07$ & $1.40 \mathrm{E}-05$ & $1.40 \mathrm{E}-05$ \\
\hline
\end{tabular}

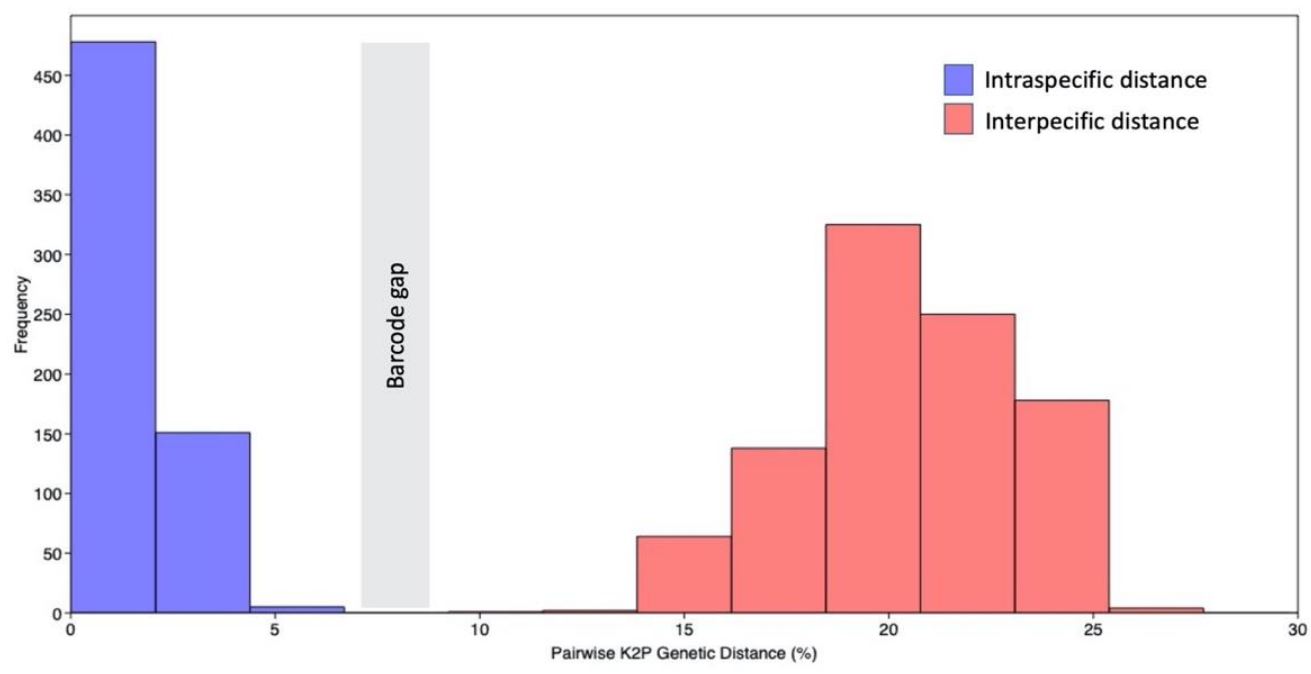

Figure 1. The intra-and inter-specific comparisons of COI gene for oil palm pollination weevil species 


\section{Genetic diversity}

A total of 36 mitochondrial COI sequences of $684 \mathrm{bp}$ length were analyzed to evaluate the genetic diversity of $E$. kamerunicus populations from 6 different locations. Three types of basic descriptive indices, namely number of polymorphism site (S), haplotype diversity (Hd), and nucleotide diversity $(\mathrm{Pi})$ were calculated to measure genetic diversity within populations (Table 5). The number of polymorphism sites (S) ranged from 3 to 37 . The number of haplotypes per population ranged from 4 to 6 . Polymorphisms were found in 6 populations that ranged from 0.8 to 1 and nucleotide diversity ranged from 0.00146 to 0.02914 . This study showed that there were genetic variations among E. kamerunicus population from Indonesia, Malaysia, and Cameroon. Among them, CD population showed the highest haplotype diversity and IB population showed the lowest haplotype diversity. The highest nucleotide diversity was found in MD population and the lowest nucleotide diversity was found in IB population.

Table 5. Genetic diversity of E. kamerunicus population from Cameroon, Malaysia, and Indonesia.

\begin{tabular}{cccccc}
\hline Population & $\mathbf{n}$ & $\mathbf{S}$ & $\mathbf{h}$ & $\mathbf{H d}$ & $\mathbf{P i}$ \\
\hline CD & 6 & 37 & 6 & 1 & 0.0269 \\
MD & 6 & 36 & 5 & 0.93333 & 0.02914 \\
IS & 6 & 3 & 5 & 0.93333 & 0.00224 \\
ID & 6 & 3 & 4 & 0.8 & 0.00146 \\
IT & 6 & 3 & 4 & 0.86667 & 0.00175 \\
IM & 6 & 11 & 4 & 0.86667 & 0.00575 \\
\hline
\end{tabular}

Notes. $n$, number of individuals; S, number of polymorphic sites; $\mathrm{h}$, number of haplotypes; $\mathrm{Hd}$, haplotype diversity; Pi, nucleotide diversity.

\section{Haplotype network}

Relationships among COI haplotypes were inferred using a haplotype network. The haplotype network was constructed using the Minimum Spanning Network (MSN) analysis (Figure 3). MSN constructed from 14 haplotypes demonstrated that several haplotypes were highly common and shared by many locations.

\section{Neutrality test}

For all sites, Tajima's D and Fu's Fs test did not reveal any significant departure from neutrality (Table 6), which may indicate population expansion or purifying selection. The only exception was that Fu's FS revealed significant departure from neutrality for population from Indonesia, North Sumatra, Siantar (IS). Significant negative results of neutrality tests indicated an excess number of alleles. This is an indication of population expansion and genetic hitchhiking.

\section{Distribution of individuals in haplogroup}

As shown in Figure 2, E. kamerunicus population taken from 6 different locations representing 3 countries formed 3 haplogroups. Haplogroup I is E. kamerunicus from CD and MD. Haplogroup II is E. kamerunicus from CD, MD, and IM. Whereas Haplogroup III is E. kamerunicus population from all sampling locations.

The distribution of individuals in haplogroups can be seen in Table 7. It can be seen that the Haplogroups differed in their geographic distribution. Most of the individuals from every 6 populations were in haplogroup III. Only, individuals from Indonesia, Central Sulawesi (IM) were in haplogroup II and the rest is from Malaysia (MD) and Cameroon (CD). Interestingly there is no individual from Indonesia in haplogroup I. This means that the haplogroup I was specific only to populations from Malaysia (MD) and Cameroon (CD).

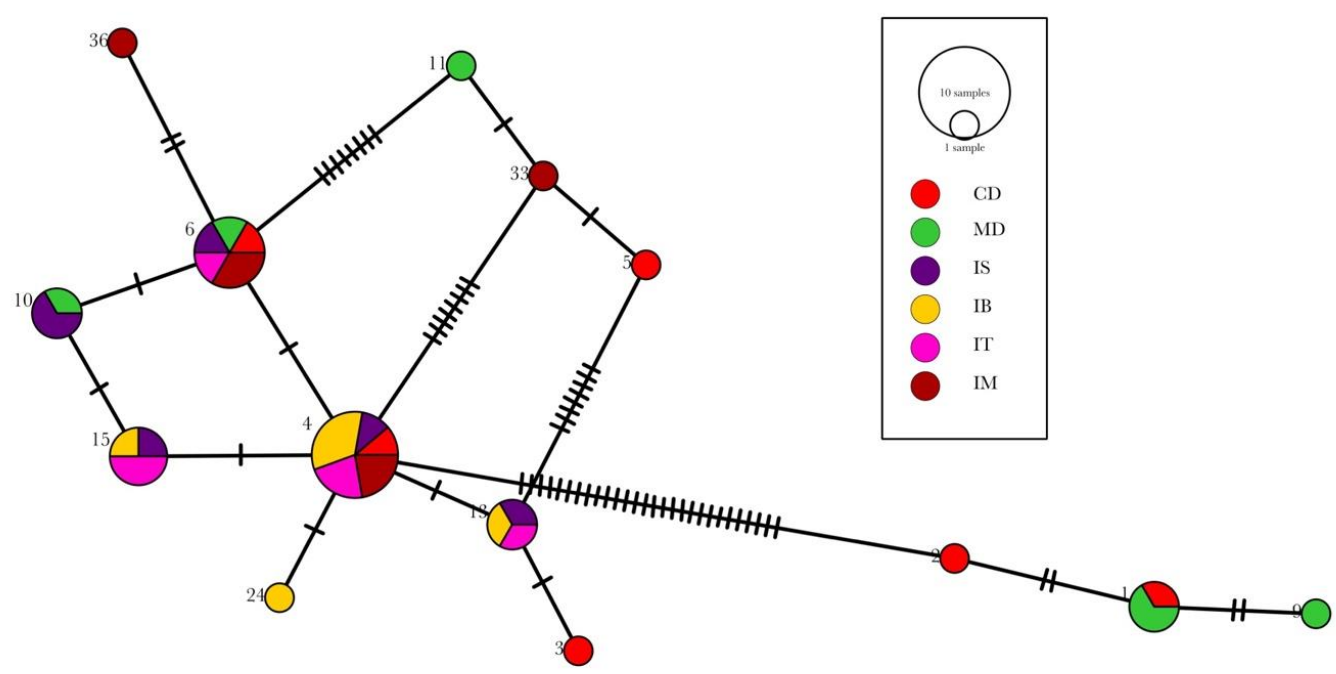

Figure 3. Haplotypes relationships using Minimum Spanning Network, size of nodes and pie segments were proportional to haplotype frequency 


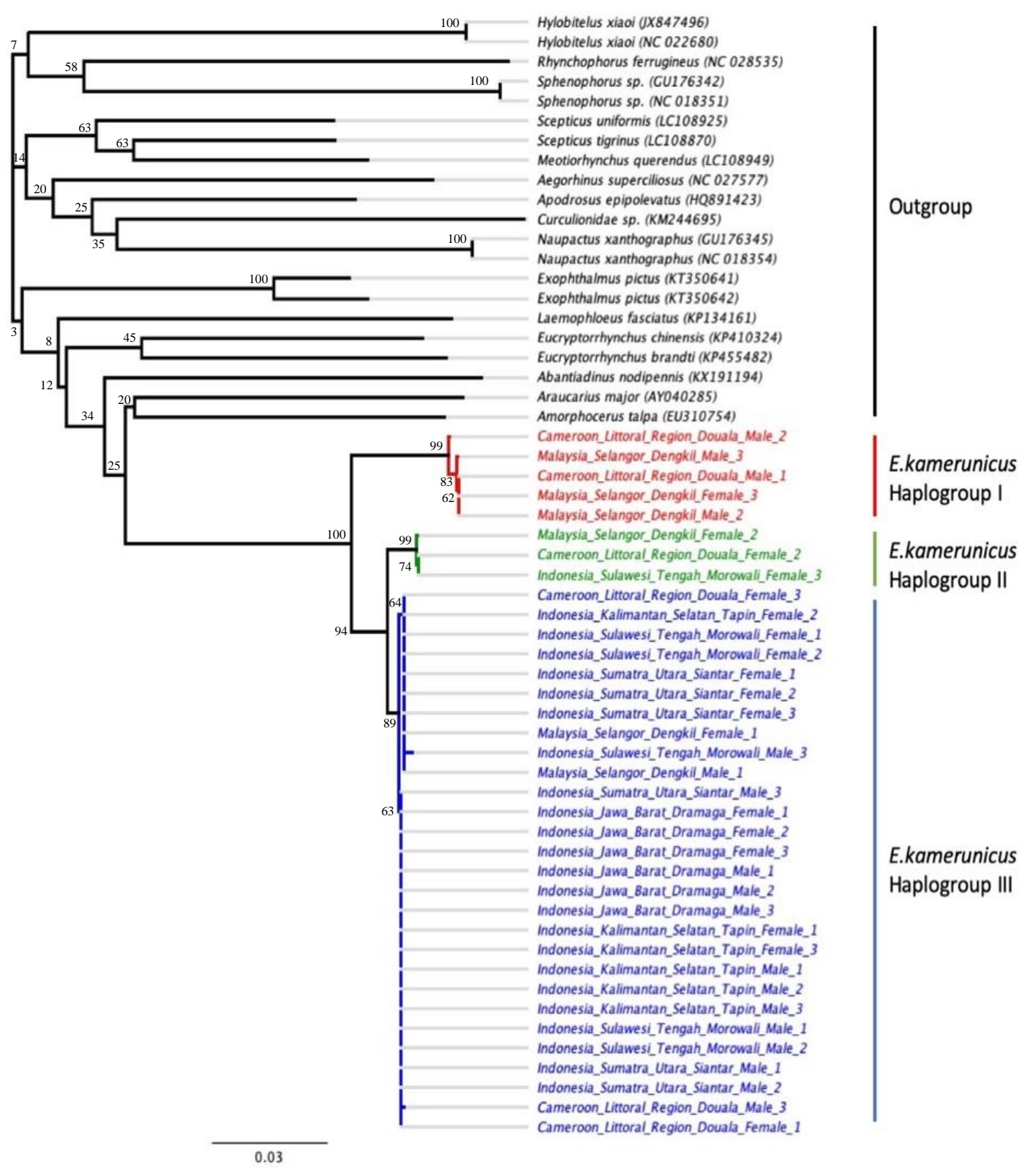

Figure 2. Phylogenetic relationship of E. kamerunicus based on partial COI sequences. Neighbor-joining tree using Kimura-2Parameter (K2P) with 1000 Bootstrap

\section{Genetic differentiation}

Analysis of pairwise FST and AMOVA gave first insight to genetic differentiation between populations. FST and AMOVA results showed significant genetic structure between population, with $\sim 21 \%$ of the variation among populations and $\sim 78 \%$ of the variation within populations (Table 8). This means that there is significant genetic differentiation among populations tested in this study.

The values of pairwise FST range from 0 to 0.39 . From 21 comparisons, two showed significantly high genetic differentiation. Referring to the criterion for genetic differentiation by (Wright 1984), genetic differentiation was defined as low for FST<0.05, moderate for $0.05<\mathrm{FST}<0.15$, high for $0.15<\mathrm{FST}<0.25$, and very high for FST $>0.25$ (Figure 4).
The pairwise FST values between Indonesia populations were less than 0.12 , indicating low to moderate genetic differentiation. The pairwise FST values between the populations from Cameroon (CD) and Malaysia (MD) were 0 , indicating a low genetic differentiation. FST values between populations from Cameroon and Indonesia range from 0.12 to 0.2 , suggesting a relatively moderate to high genetic differentiation. Interestingly, the values of pairwise genetic distance between Malaysia and Indonesia population range from 0.31 to 0.39 , indicating very high genetic differentiation. However, based on statistical significance at $\mathrm{p}$-value $<0.05$, the only significant differences were observed between populations from IT and MD and between population from IB and MD. 
Table6. Neutrality Test. Fu's Fs: Statistical significance: Not significant, $\mathrm{P}>0.01$. Tajima's $D$ : Statistical significance: Not significant, $\mathrm{P}>0.01$.
Table 7. Distribution of individuals in haplogroups. Number of individuals falling in haplogroups 1,2 , and 3 for each sampling location.

\begin{tabular}{|c|c|c|c|c|c|c|c|c|}
\hline Population & Tajima's D & $\begin{array}{c}\text { Tajima's D } \\
\text { p-value }\end{array}$ & FS & $\begin{array}{c}\text { FS } \\
\text { p-value }\end{array}$ & Population & $\begin{array}{c}\text { Haplogroup } \\
\text { I }\end{array}$ & $\begin{array}{c}\text { Haplogroup } \\
\text { II }\end{array}$ & $\begin{array}{c}\text { Haplogroup } \\
\text { III }\end{array}$ \\
\hline CD & 0.86293 & 0.808 & -0.09971 & 0.316 & CD & 2 & 1 & 3 \\
\hline MD & 1.68211 & 0.984 & 1.9712 & 0.775 & MD & 3 & 1 & 2 \\
\hline IS & 0.86222 & 0.803 & $-2.71146^{*}$ & 0.009 & IS & 0 & 0 & 6 \\
\hline ID & -1.23311 & 0.09 & -1.81298 & 0.016 & ID & 0 & 0 & 6 \\
\hline IT & -0.44736 & 0.315 & -1.45444 & 0.049 & IT & 0 & 0 & 6 \\
\hline IM & -1.11 & 0.166 & 0.72954 & 0.63 & IM & 0 & 1 & 5 \\
\hline
\end{tabular}

Table 8. Analysis of Molecular Variation (AMOVA). * Statistical significance: Significant at $\mathrm{P}<0.01$.

\begin{tabular}{lcccc}
\hline \multicolumn{1}{c}{ Source of variation } & d.f. & Sum of squares & Variance components & Percentage of variation \\
\hline Among populations & 5 & 51.139 & $1.06574 \mathrm{Va}$ & 21.75 \\
Within populations & 30 & 115 & $3.83333 \mathrm{Vb}$ & 78.25 \\
Total & 35 & 166.139 & 4.89907 & \\
Fixation Index & FST & $0.21754^{*}$ & & \\
\hline
\end{tabular}

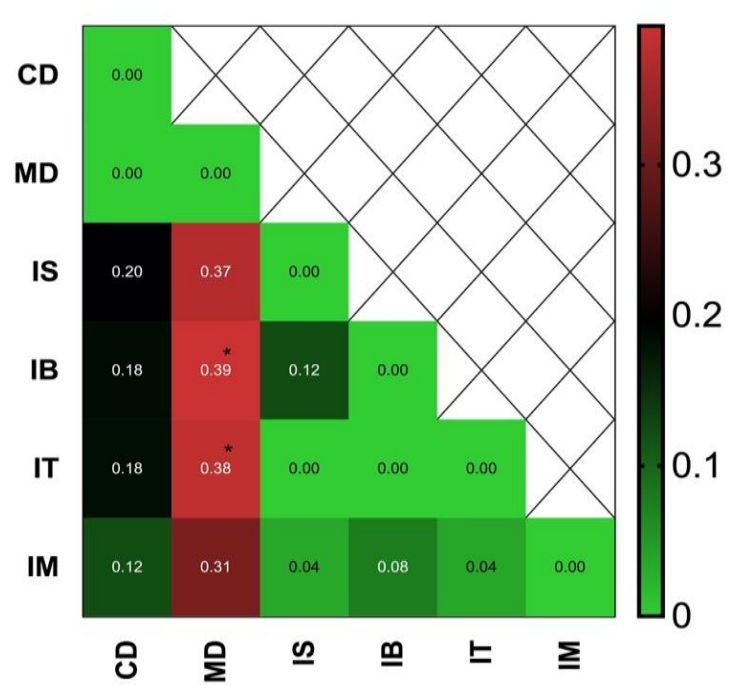

Figure 4. Pairwise Fst between E.kamerunicus population. Negative values converted to 0 . Significance level at $p<0.05$

\section{Discussion}

The use of the COI gene as a genetic marker in the identification of E. kamerunicus has been successfully demonstrated in this study. This is proven by the existence of a barcode gap that distinguishes between intraspecific and interspecific and it is clearly visible on the K2P histogram and phylogenetic tree. The species identification is considered success when the barcoding gap was detected (Meyer and Paulay 2005; Meier et al. 2008). This method also successfully assessed the power of COI as DNA barcoding marker in another insect species such as ladybird beetles (Coleoptera: Coccinellidae) (Wang et al. 2019), fish species (Imtiaz et al. 2017; Bramandito et al. 2018), coffee pollinator insects (Sitompul et al. 2018), Xyleborus sp. (Coleoptera: Scolytinae) (Chang et al. 2014) or even a general soil insect (Nyamwasa et al. 2017).

Based on these two approaches, the COI sequences are strongly recommended to be used as DNA barcoding for molecular identification of E. kamerunicus species. The sequences obtained in this study were neither found nor had any high similarity in both BoLD and NCBI databases. This means that there is no E. kamerunicus COI that has been deposited in these databases before. Therefore, this research is the first study that used COI in E. kamerunicus population for molecular identification.

The results of this study also showed that the COI gene of E. kamerunicus from Cameroon is still carried in the population of Indonesia and Malaysia. This means that it is consistent with the history of the introduction of $E$. kamerunicus in Malaysia and Indonesia, where the population of E. kamerunicus in Malaysia and Indonesia started from Cameroon population.

Phylogenetic trees constructed using the COI gene indicate the presence of 3 haplogroups, while $E$. kamerunicus from Indonesia only have 2 of them. After 30 years of introduced in Indonesia and Malaysia, the genetic diversity of E. kamerunicus populations from Cameroon was different from population from Indonesia and Malaysia. The samples from Indonesia and Malaysia possess a reduction in genetic diversity based on COI gene in comparison to Cameroon population.

This study shows a decrease in the genetic diversity of E. kamerunicus populations in Indonesia and Malaysia. One factor that causes a decrease in genetic variation is population size. This has been proven before by Soule (1976) and Furlan et al. (2011) who conducted research on 
Ornithorhynchus anatinus and lizard. The results of his research showed intraspecific genetic variation was positively correlated with population size. So, the decline in genetic variations that occur in E. kamerunicus population in Indonesia and Malaysia can be accepted, given the population of E. kamerunicus in Indonesia comes from 508 individuals who were introduced 30 years ago

However, based on current data, we cannot conclude the global dispersion and distribution pattern of E.kamerunicus populations. We would need more loci and more samples in order to clearly elucidate the demographic history and the major dispersal routes of E.kamerunicus into Indonesia from Cameroon.

\section{ACKNOWLEDGEMENTS}

We thank to management of PT. Astra Agro Lestari, Tbk. especially Santosa (CEO) and M. Hadi Sugeng (R\&D Director) for all of the supports. We also thank Dr. Vengeta Rao and the Indonesian Oil Palm Research Institute (IOPRI) team for sample collection.

\section{REFERENCES}

Bakara RD. 2019. Morfometri dan Karakter Molekuler Elaeidobius kamerunicus FAUST. (Coleoptera: Curculionidae) di Indonesia. [Thesis]. IPB University, Bogor. [Indonesian]

Bakara RD, Tambunan V, Apriyanto A, Kusumah YM, Sahari B, Buchori D. 2020. Genetic diversity and population structure in Elaeidobius kamerunicus (Coleoptera: Curculionidae) inferred from mtDNA COI and microsatellite markers. Proceedings of International Conference and the $10^{\text {th }}$ Congress of the Entomological Society of Indonesia (ICCESI 2019). Atlantis Press, Paris.

Benson D, Karsch-Mizrachi I, Clark K, Lipman D, Ostell J, Sayers E. 2012. GenBank. Nucleic Acids Res 40: 48-53.

Bramandito A, Subhan B, Prartono T, Anggraini NP, Januar HI, Madduppa HH. 2018. Genetic diversity and population structure of Siganus fuscencens across urban reefs of Seribu Islands, Northern of Jakarta, Indonesia. Biodiversitas 19 (6): 1993-2002. DOI: 10.13057/biodiv/d190603

Chang H, Liu Q, Hao D, Liu Y, An Y, Qian L, Yang X. 2014. DNA barcodes and molecular diagnostics for distinguishing introduced Xyleborus (Coleoptera: Scolytinae) species in China. Mitochondrial DNA 25 (1): 63-69. DOI: 10.3109/19401736.2013.779260

Cox CB, Moore PD, Ladle R. 2016. Biogeography: An Ecological and Evolutionary Approach. John Wiley \& Sons, New York.

Crozier R, Crozier Y. 1993. The mitochondrial genome of the honeybee Apis mellifera: Complete sequence and genome organization. Genetics 133 (1): 97-117.

Excoffier L, Lischer HE. 2010. Arlequin suite ver 3.5: A new series of programs to perform population genetics analyses under Linux and Windows. Mol Ecol Res 10 (3): 564-567. DOI: 10.1111/j.17550998.2010.02847.x

Fu Y-X. 1997. Statistical tests of neutrality of mutations against population growth, hitchhiking and background selection. Genetics 147 (2): 915-925

Furlan E, Stoklosa J, Griffiths, Gust N, Ellis R, Huggins RM, Weeks AR. 2011. Small population size and extremely low levels of genetic diversity in island populations of the platypus, Ornithorhynchus anatinus. Ecol Evol 2 (4): 844-857. DOI: 10.1002/ece3.195.
Hebert PD, Cywinska A, Ball SL, Dewaard JR. 2003. Biological identifications through DNA barcode. Proc R Soc London Ser B Biol Sci 270 (1512): 313-321. DOI: 10.1098/rspb.2002.2218.

Hebert PD, Ratnasingham S, Zakharov EV, Telfer AC, Levesque-Beaudin V, Milton MA, Pedersen S, Jannetta P, deWaard JR. 2016. Counting animal species with DNA barcodes: Canadian insects. Phil Trans R Soc B Biol Sci 371 (1702): 20150333. DOI: 10.1098/rstb.2015.0333

Hoy MA. 2003. Insect molecular genetics: An Introduction to Principles and Applications. Elsevier, Amsterdam.

Imtiaz A, Nor SAM, Naim DM. 2017. Review: Progress and potential of DNA barcoding for species identification of fish species. Biodiversitas 18 (4): 1394-1405. DOI: 10.13057/biodiv/d180415

Kumar S, Stecher G, Li M, Knyaz C, Tamura K. 2018. MEGA X: Molecular evolutionary genetics analysis across computing platforms. Mol Biol Evol 35 (6): 1547-1549.

Larkin MA, Blackshields G, Brown N, Chenna R, McGettigan PA, McWilliam H, Valentin F, Wallace IM, Wilm A, Lopez R. 2007. Clustal W and Clustal X version 2.0. Bioinformatics 23 (21): 29472948

Leigh JW, Bryant D. 2015. Popart: Full-feature software for haplotype network construction. Methods Ecol Evol 6 (9): 1110-1116. DOI: 10.1111/2041-210X.12410

Lubis AU. 1992. Kelapa sawit (Elaeis guineensis jacq.) di Indonesia. Pusat Penelitian Perkebunan Marihat, Medan. [Indonesian]

Meier R, Zhang G, Ali F. 2008. The use of mean instead of smallest interspecific distances exaggerates the size of the "barcoding gap" and leads to misidentification. Syst Biol 57 (5): 809-813. DOI: 10.1080/10635150802406343.

Meyer CP, Paulay G. 2005. DNA barcoding: Error rates based on comprehensive sampling. PLoS Biol 3 (12): e422. DOI: 10.1371/journal.pbio.0030422

Nyamwasa I, Li K, Yin J, Zhang S, Kajuga J, Hategekimana A, Waweru B, Li H. 2017. Occurrence of soil insect pests: Insight from classical identification supplemented with DNA barcoding. Intl J Pest Manag 63 (1): 18-29. DOI: 10.1080/09670874.2016.1211771

Ratnasingham S, Hebert PD. 2007. BOLD: The Barcode of Life Data System (http://www.barcodinglife.org). Mol Ecol Notes 7 (3): 355364.

Rozas J, Ferrer-Mata A, Sánchez-DelBarrio JC, Guirao-Rico S, Librado P, Ramos-Onsins SE, Sánchez-Gracia A. 2017. DnaSP 6: DNA sequence polymorphism analysis of large data sets. Mol Biol Evol 34 (12): 3299-3302. DOI: $10.1093 / \mathrm{molbev} / \mathrm{ms} \times 248$.

Schmitt T, Haubrich K. 2008. The genetic structure of the mountain forest butterfly Erebia euryale unravels the late Pleistocene and postglacial history of the mountain coniferous forest biome in Europe. Mol Ecol 17 (9): 2194-2207. DOI: 10.1111/j.1365-294X.2007.03687.x

Sitompul AF, Siregar EH, Roesma DI, Dahelmi, Prasetya E. 2018. Molecular identification of coffee (Coffea arabica) pollinator insects in North Sumatra, Indonesia based on designed COI primers. Biodiversitas 19 (5): 1877-1883. DOI: 10.13057/biodiv/d190539

Soule ME. 1976. Allozyme variation, its determinants in space and time. In: Ayala FJ (ed.). Molecular Evolution. Sinauer, Sunderland, MA.

Smith DR. 1991. Mitochondrial DNA and honey bee biogeography. Diversity in The Genus Apis 131-176. Westview press, Colorado.

Tajima F. 1989. Statistical method for testing the neutral mutation hypothesis by DNA polymorphism. Genetics 123 (3): 585-595.

Ursing BM, Arnason U. 1998. The complete mitochondrial DNA sequence of the pig (Sus scrofa). J Mol Evol 47 (3): 302-306.

Wang Z-L, Wang T-Z, Zhu H-F, Wang Z-Y, Yu X-P. 2019. DNA barcoding evaluation and implications for phylogenetic relationships in ladybird beetles (Coleoptera: Coccinellidae). Mitochondrial DNA Part A 30 (1): 1-8. DOI: 10.1080/24701394.2018.1446950

Weir BS, Cockerham CC. 1984. Estimating F-statistics for the analysis of population structure. Evolution 38 (6): 1358-1370.

Wright S. 1984. Evolution and The Genetics of Populations, Volume 4: Variability Within and Among Natural Populations. University of Chicago Press, Chicago, IL.

Zein MSA, Prawiradilaga DM. 2013. DNA Barcode Fauna Indonesia. Prenada Media, Jakarta. 